\title{
The Polish Centre for Life Cycle Assessment - the centre for life cycle assessment in Poland
}

\author{
Joanna Kulczycka • Przemysław Kurczewski • \\ Jędrzej Kasprzak • Anna Lewandowska • \\ Robert Lewicki • Agata Witczak • Joanna Witczak
}

Received: 2 November 2010 / Accepted: 9 March 2011 /Published online: 19 April 2011

(C) The Author(s) 2011. This article is published with open access at Springerlink.com

\begin{abstract}
The Polish Centre for life cycle assessment (LCA) is a non-profit organization founded in 2009 following the initiative of people involved in Polish scientific and R\&D centers dealing with LCA. The role, mission as well structure and organization of PCLCA have been presented. Moreover, the current state of LCA implementation in Poland has been mentioned. However, LCA has been mainly used for scientific research less by industry and business.
\end{abstract}

Keywords Life $\cdot$ Cycle $\cdot$ Assessment $\cdot$ Poland

\section{Inspiration}

Life cycle assessment (LCA) is a global tool (Udo de Haes et al. 2004) with a wide range of applications (Hunkeler and Rebitzer 2005). At present, life cycle assessments are carried out in a number of different countries on all continents (Klöpffer and Heinrich 2005). Since 2004, when a new branch of SETAC for Central Eastern European Countries (CEEC SETAC) was founded, LCA has also

\footnotetext{
J. Kulczycka $(\bowtie)$

Mineral and Energy Economy Research Institute,

Polish Academy of Sciences,

31-261 Cracow, Poland

e-mail: kulczycka@meeri.pl

P. Kurczewski $\cdot$ J. Kasprzak

Faculty of Working Machines and Transportation,

Poznan University of Technology,

60-965 Poznan, Poland
}

A. Lewandowska $\cdot$ R. Lewicki $\cdot$ A. Witczak $\cdot$ J. Witczak Faculty of Commodity Science, Poznan University of Economics, 61-875 Poznan, Poland become increasingly popular in Poland. This fact can be attributed to Poland's accession to the European Union. First, because it required the adaptation of Polish law to the EU regulations which recommend using LCA. Second, the accession allowed Polish scientists to join the EU fellowship system resulting in the transfer of knowledge and experience, also in the area of life cycle-based tools. To sum up, LCA is present in Polish law regulations (Kulczycka 2009), in scientific research (Czaplicka-Kolarz et al. 2004; Klos 1999, 2000, 2002; Kowalski et al. 2007; Kurczewski and Lewandowska 2010; Lewandowska and Foltynowicz 2004; Lewandowska et al. 2004, 2008, 2011) and, to a fairly limited extent, in university syllabuses and business. The key to making life cycle approaches more popular in Poland and establishing Poland's position in the international arena seems to be the effective cooperation of domestic scientific centers, companies, and government bodies. Moreover, when examining LCA tasks on a national level, the following methodological challenges can be mentioned: determining normalization flows, identifying regionally differentiated characterization factors, or a survey among Polish people to identify their weighting preferences.

The establishment of the Polish Centre for LCA was motivated by the willingness to face these challenges and the urge to follow the example of other organisations (ACLCA; Grant et al. 2001; Hur 1999; Itsubo 2000; Nakano et al. 2007; Sharma 2000), which foster the concept of life cycle assessment.

\section{PCLCA's mission}

The Polish Centre for LCA is a non-profit organization (PCLCA 2010), founded in 2009 following the initiative of people involved in Polish scientific and R\&D centres 
dealing with the LCA and other tools of products life cycle management. The implementation of these tools, highly popular worldwide, in the Polish market can make Polish companies more competitive, both locally and globally. The main objectives of the Polish Centre for LCA are:

- To stimulate the integration of life cycle approaches into the decision-making process of organizations;

- To increase the global competitiveness of Polish companies through implementing solutions widely used in advanced industrialized countries;

- To cooperate with public administration bodies in the area of: Green Public Procurement; Integrated Product Policy; industry analysis; BAT; ecolabelling; and green tax reform;

- To promote the concept of life cycle assessment among companies doing business in Poland;

- To introduce an action plan to improve the credibility of LCA carried out in Poland through collecting and processing data representative of Poland and the verification of assessments with regard to the requirements of ISO 14040x standards; and

- To provide solutions to some methodology nationspecific problems related to LCI and LCIA phases.

\section{PCLCA's operations and structure}

The organizational structure of PCLCA consists of two parts. The operational activities (training, LCA case studies, peer reviews, and scientific projects) are performed by PCLCA members acting as consultants. At present, they primarily include the PCLCA's founders, but the involvement of other people will be welcome. The consultants play the operational role. The scientific board is designed as the second structural part of PCLCA to play the advisory and reviewing role. The PCLCA's scientific board is composed of people recognized as authorities on LCA (methodologists, developers, and practitioners) coming from Polish and foreign centres. Presently, the scientific board consists of three members from Poland:

- Professor Zenon Foltynowicz from Poznan University of Economics, Poland;

- Professor Zbigniew Klos from Poznan University of Technology, Poland; and

- Professor Zygmunt Kowalski from Cracow University of Technology.

According to its mission statement, PCLCA is focused on advising and training in the wide range of areas: from LCA to Green Public Procurement, ecolabelling, and Integrated Product Policy. These issues have received a lot of attention recently, which justifies the existence of the centre.
PCLCA is also willing to cooperate with domestic and foreign centres. Since Polish experience in life cycle-based analyses is still relatively low, any involvement of more experienced centres will be valuable and welcome. One example of this type of initiative is the recent cooperation of PCLCA and Chalmers University of Technology in Goeteborg and Green DeltaTC in Berlin. Two areas of interest in the cooperation can be distinguished: the potential of LCA as a tool for identifying and assessing the environmental aspects in environmental management systems and the presence of LCA and other related issues in the international exchange trade.

Another field worth exploring by PCLCA is university education. LCA is now the subject of research of a number of scientific centres in Poland. However, it has only been discussed in degree papers (such as engineer's degree, $\mathrm{PhD}$, and postdoctoral theses), but little has been done to include it in university syllabuses. Only a few universities offer courses devoted to this issue. That is why it is important to write an accessible, but comprehensive LCA university course book.

\section{Conclusions}

The effective introduction and development of the principles of life cycle assessment in Poland requires the involvement and coordinated collaboration of many centres as well as raising necessary funds. The implementation of LCA and similar models into business practice not only involves promotional and training activities, but also necessitates educating the whole bunch of young employees, who will possess totally new knowledge and capabilities. The activities of particular institutions will not be enough, if they are not backed by university graduates, who bring "the life cycle spirit" to decision-making processes in organizations.

Open Access This article is distributed under the terms of the Creative Commons Attribution Noncommercial License which permits any noncommercial use, distribution, and reproduction in any medium, provided the original author(s) and source are credited.

\section{References}

ACLCA American Centre for Life Cycle Assessment. http://www. lcacenter.org/. Accessed 20 October 2010

Czaplicka-Kolarz K, Wachowicz J, Bojarska-Kraus M (2004) A life cycle method for assessment of a colliery's eco-indicator. Int $\mathrm{J}$ Life Cycle Assess 9(4):247-253

Grant T, James KL, Lundie S, ALCAS: Australian LCA society (2001) New LCA group to promote life cycle assessment in Australia. Int J Life Cycle Assess 6(6):323-324 
Hunkeler D, Rebitzer G (2005) Editorial: the future of life cycle assessment. Int J Life Cycle Assess 10(5):305-307

Hur $T$ (1999) Activities of the Korean society for life cycle assessment. Int J Life Cycle Assess 4(5):247-248

Itsubo N (2000) JLCA corner (Life Cycle Asssessment Society in Japan). Int J Life Cycle Assess 5(1):4

Klöpffer W, Heinrich AB (2005) Editorial: 2005-the 10th anniversary volume of Int J LCA. Int J Life Cycle Assess 10(2):95-96

Klos Z (1999) LCA in Poland: background and state-of-art. Int J of LCA 7(5):249-250

Klos Z (2000) First PhD thesis on LCA in Poland: ecobalancing of machines and devices with the example of air compressors. Int $\mathrm{J}$ Life Cycle Assess 5(1):19-20

Klos Z (2002) Ecobalancial assessment of chosen packaging processes in food industry. Int J Life Cycle Assess 7(5):309

Kowalski Z, Kulczycka J, Wzorek Z (2007) Life cycle assessment of different variants of sodium chromate production in Poland. J Clean Prod 15(1):28-37

Kulczycka J (2009) Life cycle thinking in Polish official documents and research. The determination of discount rate for green public procurement. Int J Life Cycle Assess 14(5):375-378

Kurczewski P, Lewandowska A (2010) ISO 14062 in theory and practice - ecodesign procedure. Part 2: practical application. Int J Life Cycle Assess 15(8):777-784
Lewandowska A, Foltynowicz Z (2004) Comparative LCA of industrial objects. Part 2: case study for chosen industrial pumps. Int J Life Cycle Assess 9(3):180-186

Lewandowska A, Foltynowicz Z, Podlesny A (2004) Comparative LCA of industrial objects. Part 1: LCA data quality assurance - sensitivity analysis and pedigree matrix. Int J Life Cycle Assess 9(2):86-89

Lewandowska A, Wawrzynkiewicz Z, Noskowiak A, Foltynowicz Z (2008) Adaptation of ecoinvent database to Polish conditions. The case of wood production in the forest. Int $\mathrm{J}$ Life Cycle Assess 13(4):319-327

Lewandowska A, Matuszak-Flejszman A, Joachimiak K, Ciroth A (2011) Environmental Life Cycle Assessment as a tool for identification and assessment of environmental aspects in environmental management systems (EMS) part 2. Int J Life Cycle Assess 16(3):247-257

Nakano K, Nakaniva C, Kabeya T, Iguchi T, Aoki R (2007) Current activities of the Life Cycle Assessment Society of Japan. Int J Life Cycle Assess 12(7):546

PCLCA (2010) http://www.pclca.org. Accessed 20 October 2010

Sharma KV (2000) Indian Society for Life Cycle Assessment. Int J Life Cycle Assess 5(1):4

Udo de Haes HA, Heijungs R, Suh S, Huppes G (2004) Three strategies to overcome the limitations of life-cycle assessment. J Ind Ecol 8(3):19-32 